\title{
Risk Management for New Product Development Projects in Food Industry
}

\author{
Dundusid Porananond ${ }^{1}$ and Natcha Thawesaengskulthai ${ }^{2}$ \\ ${ }^{1} \mathrm{PhD}$ Candidate, Technopreneurship and Innovation Management Program, Chulalongkorn University, Phayathai road, \\ Pathumwan, Bangkok 10330, Thailand. E-mail: dundusid@gmail.com \\ ${ }^{2}$ Assistant Professor, Department of Industrial Engineering, Faculty of Engineering, Chulalongkorn University, \\ Pathumwan, Bangkok 10330, Thailand. E-mail: natcha.t@ chula.ac.th (corresponding author).
}

Project Management

Received January 19, 2014; received revision April 24, 2014; accepted May 9, 2014

Available online May 30, 2014

\begin{abstract}
Project risk management provides a guideline for decision making in new product development (NPD) projects, reducing uncertainty and increasing success rate. However, the acceptance of formal risk management applications in industry, especially for NPD projects is still in question. A study of a food conglomerate in Thailand found that only $9 \%$ of NPD projects used a systematic approach for managing risk. $61 \%$ of the projects realised the importance of risk management, while the remaining 30\% did not involve risk management at all. This study aims to develop a risk management model for NPD projects in the food industry. The first section of this paper reviews the literature on risk management theory, including international standards for risk and project management (ISO31000 and ISO21500), publications for the Project Management Body of Knowledge (PMBOK), by a professional organisation the Project Management Institute (PMI), and also academic research. 182 academic papers, published between January 2002 and August 2012 were selected. The second part interviews conducted with eight NPD experts from five of the major food manufacturers in Thailand to examine their risk management practices and problems. Conclusions are made on five topics : classification of research method, project type and industrial segment, distribution of articles by region, tools \& techniques for risk management and risk factors in projects. Specific requirements of risk management for NPD projects in the food industry are identified. A risk management model and the concept of risk management applications for the food industry are proposed.
\end{abstract}

Keywords: Project management, risk management, new product development, risk factor, food industry.

\section{Introduction}

Project management is widely used in industry. It is utilised for all project types, from manufacturing, engineering, marketing, and new product development (NPD). The increasing acceptance and practice of project management in industry indicates that the application of appropriate knowledge, processes, skills, tools, and techniques can have a significant impact on project success (PMI, 2008).

Risk management is an essential element in project success. It is an important activity and should be applied to all projects as an integral part of every aspect of managing the project, in every phase and in every process group. (PMI, 2009). The management of risks in projects is a growing area of concern (Maytorena et al., 2007). Chapman and Ward (2004) and Aloini et al. (2012) concluded that risk management can lead to a range of benefits for both projects and organisations. It provides guidance for decision making about alternative options in the project, increases confidence in the project success and reduces the risk of unexpected events that can cause delays and excess expenditure.

Risk management should be used to increase the success rate of NPD projects, since many, by their nature are highly complex. A study by Stevens and Burley (2003) indicated that only $60 \%$ of NPD projects survive from inception to completion and commercialisation. Another study by Cooper (2003) concluded that successful new product development requires effective strategies for reducing risk and that knowledge management systems have the potential to aid risk reduction. Many studies in the last decade have been focused on the reasons for new product success or failure (Keizer et al., 2005). This research identified various groups of important factors related to managerial issues in NPD, such as product performance, marketing issues, organisation synergy and project management, which also includes risk management.

A guide to management innovation for organization or BS 7000-1 (BSI, 2008) also recommends that organisations perform risk assessment on their innovative 
projects (including NPD). This can assist in decision making through every step from idea generation to feasibility studies and project implementation.

Nevertheless, risk management in NPD projects for industry seem to have very low importance, and systematic processes are not usually included in NPD activities. Risk management in NPD seems to be more complex, with different issues compared to other types of project (Pinto and Covin, 1989). Several studies attempt to show the unique characteristics and particular requirements of project management in the NPD process (Milosevic and Patanakul, 2005; Thal et al., 2007; Pons, 2008). However, these studies did not explain all the problems associated with risk management in NPD. Recent studies by Ahlemann et al. $(2009,2012)$ indicated that project management methods suffer from low adoption and individual acceptance because there is a lack of universal applicability as well as consideration of the usage environment. This study attempts to understand the problem of low utilisation of risk management in greater detail by exploring the standard literature and academic papers published in the last decade.

\subsection{Risk Management Standard and Risk Management Process}

PMBOK (PMI, 2008) defines risk as an uncertain event or condition that, if it occurs, has an effect on at least one project objective. Similarly, risk management standard ISO31000 (2009) and AS/NZS 4360 (2004) define risk as the chance of something happening that will have an impact on an objective. Traditionally risk was perceived negatively but recent standards suggest that the impact of risk could be either negative or positive.

A recent study by Jafari et al. (2011) reviewed four well-known approaches to risk management: PMBOK (PMI, 2004), project risk analysis and management (PRAM) (Simon et al., 1997; Association for Project Management, 2004), management of risk (MOR) (Office of Government Commerce, 2002) and the standard AS/NZS4360 (Standards Australia/Standards New Zealand, 2004). He concluded that there was no significant difference in the risk management processes between them. The standards reviewed here may not be intended for use as the norm for project risk management directly, but they relate to project risk management in a different way. AS/NZS4360 and ISO31000 cover risk management for all organisational activities (including projects) while ISO10006, ISO21500 and PMBOK limit the scope of their coverage to project work only; risk management is an important process (or knowledge area) in their project activities. The relationship between project management and risk management processes for these four standards and $\mathrm{PMBOK}$ are explained in Table 1.

The comparison between the process steps for risk management in relation to the standards and $\mathrm{PMBOK}$ are illustrated in Fig. 1.

This shows alignment from the first step in establishing or planning for the scope of risk management, followed by the identification of the risks in the project. An analysis and evaluation for risk is then performed followed by the establishment of risk treatment or a response plan for important risks. Finally, the risk management process ends with the monitoring and control of the risks until project completion. We can summarise the key steps of project risk management as : 1) scope and context planning, 2) risk identification, 3) risk analysis, 4) risk treatment and 5) risk control. These steps will be used in the risk management model proposed in this paper.

\subsection{New Product Development Process}

New product development process methodology has a long evolutionary history. This began with 'stage-gate' systems. These were widely adopted and generally had a strong and positive impact on firms (Cooper, 1994). The first generation of this process was developed by NASA in the 1960s as NASA's PPP (phased project planning) which was also called 'Phase Review Process'. The new product process at that time was engineering driven. It focused on and applied strictly to physical design and development activities. It was designed solely to deal with technical risks and did not consider business activities at all.

The second generation stage-gate process also consisted of identifiable and discrete stages preceded by a review point or 'gate'. This was a cross functional process involving activities from many differing functions in an organisation or corporation. Sales, marketing and manufacturing functions are all integral parts of the product development process. The implementation of this second generation or stage-gate approach appears to have been successful. One study by Cooper and Kleinschmidt (1991) showed positive results from leading firms, including 3M, IBM, Nortern Telelcom and others.

The third generation stage-gate was proposed by Cooper in 1994. This was intended to overcome problems with the second generation, such as long project lead time from waiting at each gate review. The previous generation did not allow for the overlap of activities at each stage. The third generation has four fundamentals: 1) Fluidity, with overlapping stages for better speed, 2) Fuzzy gates, with conditional Go decisions, 3) Focused, prioritisation methods for the entire length of the project and 4) Flexibility, allowing each project to have its own routing through the process.

Another well-known product development process was developed by Ulrich and Eppinger in 2008. This NPD process is called 'The generic product development process'. This consists of 6 steps: planning, concept development, system-level design, detailed design, testing and refinement and production ramp-up.

The comparison of several NPD processes in Table 2 show the development trend with time. NPD started with a narrow scope which only focused on engineering and physical design. Later, the process was expanded to involve other functions in an organisation, such as sales and marketing.

Most of the NPD processes are generic and can be applied for use in different industries. However, some process models have been developed specifically for a particular industry, such as the process of innovation for health care by Varkey et al. (2008), which included additional steps for diffusion and local adaptation after commercialisation. Aleixo and Tenera (2009) proposed NPD processes in high-technology enterprises. 
Table 1. Summary of standards and PMBOK related to Project Risk Management

\begin{tabular}{|c|c|c|}
\hline Standard & Relation to Project Management & Risk Management Process \\
\hline $\begin{array}{l}\text { AS/NZS 4360:2004 Risk } \\
\text { Management }\end{array}$ & Included but not specific to project risks & $\begin{array}{l}\text { Defines risk management process } \\
\text { as } \\
\text { 1) Communicate and consult } \\
\text { 2) Establish the context } \\
\text { 3) Identify risks } \\
\text { 4) Analyse risks } \\
\text { 5) Evaluate risks } \\
\text { 6) Treat risks } \\
\text { 7) Monitor and review }\end{array}$ \\
\hline $\begin{array}{l}\text { ISO31000:2009 } \\
\text { Risk management }\end{array}$ & Included but not specific to project risks & $\begin{array}{l}\text { Defines risk management process } \\
\text { as } \\
\text { 1) Communication and consultation } \\
\text { 2) Establishing the context } \\
\text { 3) Risk assessment } \\
\text { 4) Risk treatment } \\
\text { 5) Monitoring and review }\end{array}$ \\
\hline $\begin{array}{l}\text { ISO10006:2003 Guidelines for } \\
\text { quality management in projects }\end{array}$ & $\begin{array}{l}\text { Defines project management to } 7 \text { process } \\
\text { grouping for } \\
\text { 1) Inter dependency-related processes, } \\
\text { 2) Scope-related processes, } \\
\text { 3) Time-related processes, } \\
\text { 4) Cost-related processes, } \\
\text { 5) Communication-related processes, } \\
\text { 6) Risk-related processes and } \\
\text { 7) Purchasing-related processes }\end{array}$ & $\begin{array}{l}\text { Defines risk-related processes } \\
\text { group as } 4 \text { processes } \\
\text { 1) Risk identification } \\
\text { 2) Risk assessment } \\
\text { 3) Risk treatment } \\
\text { 4) Risk control }\end{array}$ \\
\hline $\begin{array}{l}\text { ISO21500:2012 Guidance on } \\
\text { project management }\end{array}$ & $\begin{array}{l}\text { Defines project management to } 10 \text { subject } \\
\text { groups for } \\
\text { 1) Integration, 2) Stakeholder, } \\
\text { 3) Scope, 4) Resource, } \\
\text { 5) Time, 6) Cost, } \\
\text { 7) Risk , 8) Quality, } \\
\text { 9) Procurement and } \\
\text { 10) Communication. }\end{array}$ & $\begin{array}{l}\text { Defines risk subject group into } 4 \\
\text { processes } \\
\text { 1) Identify risks } \\
\text { 2) Assess risk } \\
\text { 3) Treat risk } \\
\text { 4) Control risks }\end{array}$ \\
\hline $\begin{array}{l}\text { PMBOK 5th Edition (PMI, } \\
\text { 2013) }\end{array}$ & $\begin{array}{l}\text { Defines } 10 \text { knowledge area for } \\
\text { 1) Project integration management, } \\
\text { 2) Project scope management, } \\
\text { 3) Project time management, } \\
\text { 4) Project cost management, } \\
\text { 5) Project quality management, } \\
\text { 6) Project human resource management, } \\
\text { 7) Project communication management, } \\
\text { 8) Project risk management, } \\
\text { 9) Project procurement management and } \\
\text { 10) Project stakeholder management. }\end{array}$ & $\begin{array}{l}\text { Defines risk management process } \\
\text { as } 6 \text { processes as following } \\
\text { 1) Plan risk management } \\
\text { 2) Identify risks } \\
\text { 3) Perform qualitative risk analysis } \\
\text { 4) Perform quantitative risk } \\
\text { analysis } \\
\text { 5) Plan risk responses } \\
\text { 6) Control risks }\end{array}$ \\
\hline
\end{tabular}




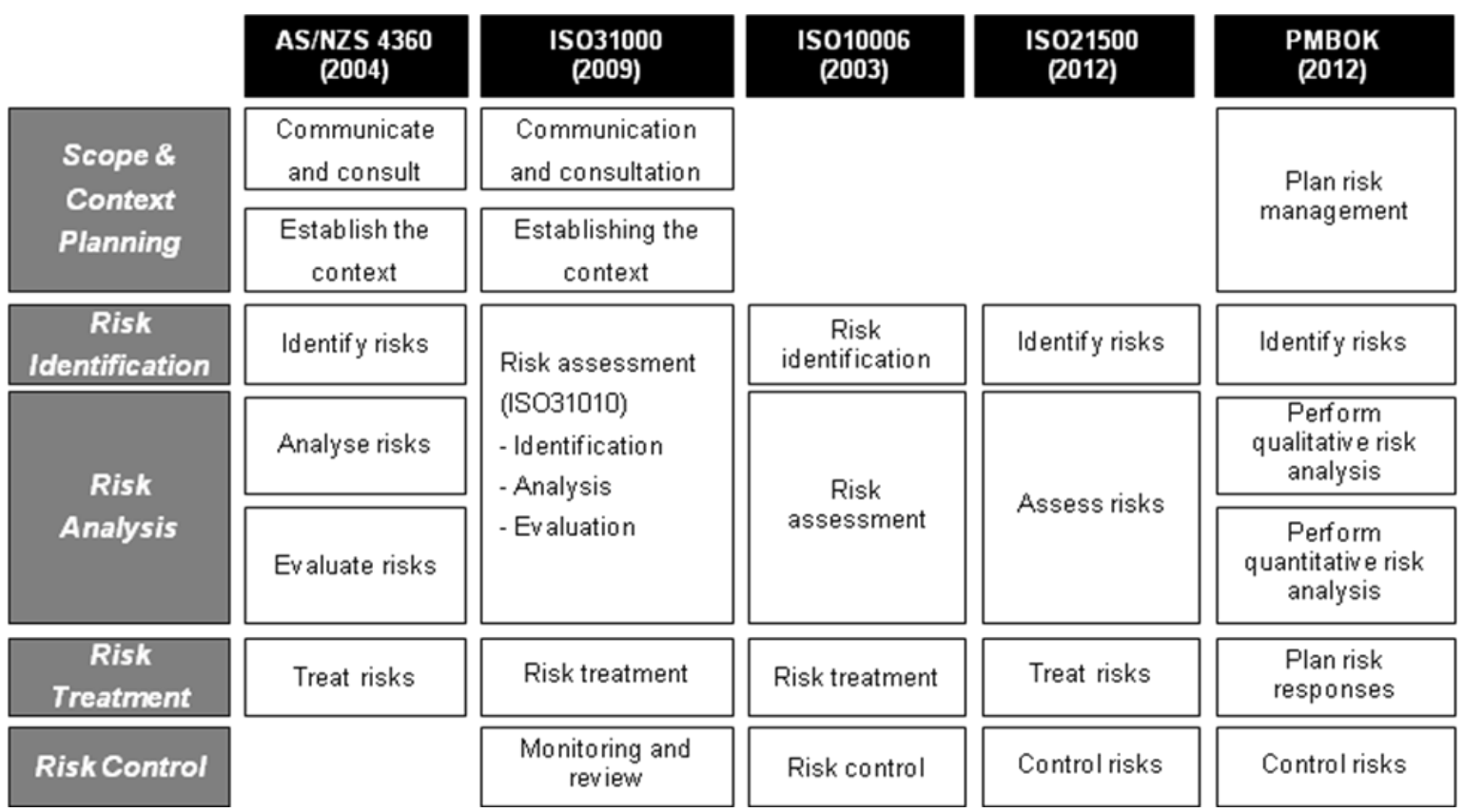

Fig. 1. Comparison of risk management process in standard and PMBOK

Table 2. Review of product development process

\begin{tabular}{|c|c|c|c|}
\hline NPD Process & NPD phase & Focus & Authors/Year \\
\hline $\begin{array}{l}\text { Phased review } \\
\text { process }\end{array}$ & $\begin{array}{l}\text { 1) Preliminary analysis, } \\
\text { 2) Definition, } \\
\text { 3) Design, } \\
\text { 4) Development, } \\
\text { 5) Operations }\end{array}$ & $\begin{array}{l}\text { Engineering driven and applied } \\
\text { strictly to physical design and } \\
\text { development process by did not } \\
\text { consider the market factor in new } \\
\text { product development }\end{array}$ & NASA, 1960s \\
\hline $\begin{array}{l}\text { 2nd Generation } \\
\text { Stage-Gate }\end{array}$ & $\begin{array}{l}\text { 1) Preliminary assessment, } \\
\text { 2) Business case, } \\
\text { 3) Development, } \\
\text { 4) Testing \& Validation } \\
\text { 5) Full production \& market launch }\end{array}$ & $\begin{array}{l}\text { More cross-functional process, } \\
\text { involves activities from many } \\
\text { different department. Marketing } \\
\text { and manufacturing become } \\
\text { integral parts of process }\end{array}$ & Cooper, 1990 \\
\hline $\begin{array}{l}\text { 3rd Generation } \\
\text { Stage-Gate }\end{array}$ & $\begin{array}{l}\text { Five Phase same as } 2 \text { nd generation } \\
\text { but allow overlapping between phase }\end{array}$ & $\begin{array}{l}\text { Focus on reduce lead time for } \\
\text { development by parallel or } \\
\text { concurrent processing }\end{array}$ & Cooper, 1994 \\
\hline $\begin{array}{l}\text { New Concept } \\
\text { Development }\end{array}$ & $\begin{array}{l}\text { 1) Opportunity identification, } \\
\text { 2) Opportunity analysis, } \\
\text { 3) Idea genesis, } \\
\text { 4) Idea selection, } \\
\text { 5) Concept \& technology } \\
\text { development }\end{array}$ & $\begin{array}{l}\text { Focus on new concept } \\
\text { development process for input to } \\
\text { design and development phase }\end{array}$ & Koen et al., 2001 \\
\hline $\begin{array}{l}\text { Typical development } \\
\text { phases }\end{array}$ & $\begin{array}{l}\text { 1) Concept development, } \\
\text { 2) Product design } \\
\text { 3) Pilot production / testing }\end{array}$ & $\begin{array}{l}\text { Focus on design and development } \\
\text { function and not include } \\
\text { manufacturing and launch phase }\end{array}$ & $\begin{array}{l}\text { Schroeder, R. G., } \\
2003\end{array}$ \\
\hline $\begin{array}{l}\text { Front-end process } \\
\text { model }\end{array}$ & $\begin{array}{l}\text { 1) Environmental screening } \\
\text { 2) Idea generation } \\
\text { 3) Concept Project and business } \\
\text { planning }\end{array}$ & $\begin{array}{l}\text { Focus in early phase of } \\
\text { innovation process }\end{array}$ & $\begin{array}{l}\text { Husig, Kohn, and } \\
\text { Poskela, } 2005\end{array}$ \\
\hline
\end{tabular}


Table 2. Review of product development process (continue)

\begin{tabular}{|c|c|c|c|}
\hline NPD Process & NPD phase & Focus & Authors/Year \\
\hline $\begin{array}{l}\text { Food Product } \\
\text { Development Process }\end{array}$ & $\begin{array}{l}\text { 1) Strategic evaluation, } \\
\text { 2) Market Assessment, } \\
\text { 3) Evaluation of company fit, } \\
\text { 4) Product definition, } \\
\text { 5) Prototype development, } \\
\text { 6) Market testing, } \\
\text { 7) Scale-up and trial production, } \\
\text { 8) Product refinement } \\
\text { 9) Final product production \& launch }\end{array}$ & $\begin{array}{l}\text { Model illustrates the FDA's role } \\
\text { in new product development of } \\
\text { food products which FDA } \\
\text { administration involved after } \\
\text { product definition and product } \\
\text { refinement phases }\end{array}$ & $\begin{array}{l}\text { Glueck- } \\
\text { Chaloupka et al., } \\
2005\end{array}$ \\
\hline $\begin{array}{l}\text { Process of Innovation } \\
\text { in Heath care }\end{array}$ & $\begin{array}{l}8 \text { process steps for } \\
\text { 1) Idea generation, } \\
\text { 2) Opportunity/ Problem recognition, } \\
\text { 3) Idea evaluation, } \\
\text { 4) Development, } \\
\text { 5) First use, } \\
\text { 6) Commercialization, } \\
\text { 7) diffusion and } \\
\text { 8) Local adaptation }\end{array}$ & $\begin{array}{l}\text { Focus on innovation development } \\
\text { for both of new product and } \\
\text { process in health care }\end{array}$ & $\begin{array}{l}\text { Varkey et al., } \\
2008\end{array}$ \\
\hline $\begin{array}{l}\text { Generic development } \\
\text { process }\end{array}$ & $\begin{array}{l}6 \text { Phase process, consists of: } \\
\text { 1) Planning, } \\
\text { 2) Concept Development, } \\
\text { 3) System-level design, } \\
\text { 4) Detail design, } \\
\text { 5) Testing \& refinement and } \\
\text { 6) Production ramp-up }\end{array}$ & $\begin{array}{l}\text { Defined development process and } \\
\text { also identifies the key activities } \\
\text { and responsibilities of different } \\
\text { functions in organization }\end{array}$ & $\begin{array}{l}\text { Ulrich and } \\
\text { Eppinger, } 2008\end{array}$ \\
\hline $\begin{array}{l}\text { NPD process for } \\
\text { High-Tech Enterprise }\end{array}$ & $\begin{array}{l}5 \text { Phase, consist of: } \\
\text { 1) Product concept } \\
\text { 2) Feasibility } \\
\text { 3) Development } \\
\text { 4) Validation and } \\
\text { 5) Commercialization }\end{array}$ & $\begin{array}{l}\text { Focus on NPD on High-Tech } \\
\text { Innovation Life Cycle }\end{array}$ & $\begin{array}{l}\text { Aleixo and } \\
\text { Tenera, } 2009\end{array}$ \\
\hline
\end{tabular}

In this paper we will focus on the food industry. Some researchers call this 'lower tech' as most of the innovation will be incremental, (Suwannaporn \& Speece, 2010). A study by Francis (2006) and Winger and Wall (2006), showed that only 2 percent of new food products can be considered as highly or radically innovative. Food producers are strongly market-driven and there is more focus on consumer acceptance (Suwannaporn \& Speece, 2010). The study by Glueck-Chaloupaka et al. (2005), discussed NPD processes for food products, but their model only focused on the role of the FDA as a regulator in food product development. Another study by Francis (2006) tried to find appropriate NPD processes for fast moving consumer products by matching the stage model processes with three case studies in three food manufacturing companies in the UK. He found that the same general principles for generic NPD processes can be applied. However, some past NPD process models failed to recognise some important steps in the food industry, such as packaging development processes.
The objective of this research is not to focus on the development of NPD processes, but to understand the risk elements that can occur during each stage. The comprehension of activities and process steps in food product development is an essential part of the conceptual background for a risk management model.

\section{Research Question and Objective of Research}

Research questions to be answered here focus on an appropriate risk management process that can be used for NPD projects; what are the issues or determinant factors of risk management in the food industry and how can the acceptance of risk management of NPD projects be improved.

Four objectives of the study can be listed : 1) to explore risk management processes in risk and project management standards, 2) to understand the conceptual background and issues in risk management for project work, 3) to study risk management practices of NPD projects in food companies in Thailand and 4) to propose a 
risk management model for NPD projects in the food industry which will include common risk factors.

\section{Research Methodology}

\subsection{Systematic Literature Review}

This is a review of articles that clearly formulate the searching strategy and method for screening. This methodology can limit bias by random selection or a nonsystematic search.

The topics of risk management and product development can be published in many journals covering different research areas. However, we included the main journals on project management such as the Project Management Journal and the International Journal of Project Management in our document collection. An initial search was run to determine the number of papers about project management and risk management in each database that can be accessed through the university network. We then selected the four databases with the highest number of publications. These are : (1) ProQuest, (2) EBSCO host, (3) Elsevier Science Direct and (4) Emerald.

\subsubsection{Inclusion criteria}

The inclusion criteria for article selection in this study are:

1) The articles were selected from the area of overlap of three main knowledge domains : project management, risk management and new product development.

2) The criteria for paper searching was not limited to papers on NPD projects only, since risk management models and methodology used in other project types might give a better understanding of differing requirements.

3) Selected articles were peer reviewed only. Book chapter, non-peer reviewed publications, and newspaper articles were not included in this study.

4) The search criteria included articles published between January 2002 and August 2012.

\subsubsection{Search criteria}

The search criteria for the literature review was as follows :

1) Papers published between January 2002 and August 8, 2012.

2) Search terms were used to search title, abstract and keywords in the database.

3) Single search terms were not used due to the broad description of the results and the excessive number of papers in each domain.

4) Some search terms do not directly relate to 'risk', but to product development and project management, these were also included.

5) The search terms consisted of the following :

- (Project Risk) AND (Product Development)

- (Project Risk) AND (Project Management)

-(Risk Analysis) AND (Product Development)

- (Risk Analysis) AND (Project Management)

- (Risk Assessment) AND (Product Development)

- (Risk Assessment) AND (Project Management)
- (Risk Management) AND (Product Development)

- (Risk Management) AND (Project Management)

- (Product Development) AND (Project Management)

A total of 2,271 papers were found from the search criteria: 427 from ProQuest database, 1507 from EBSCOhost, 248 from Elsevier Science Direct and 89 from Emerald. After removing duplicates and items without access to the full paper, the number was reduced to 1278 . These were passed to the next step, the screening process.

\subsubsection{Screening criteria}

Papers were selected through screening criteria using the following conditions :

1) Discussion on definition, framework and methodology about project risk.

2) Discussion about problems, success and risk factors of the project from a project management perspective.

3) Case studies or empirical studies relating to project risk.

4) Discussion regarding the development of tools, techniques and the application of risk management

5) Some papers not found through the search criteria, but related to important topics or used as references have also been included .

The remaining papers were screened by title and reduced to 541, then screened by abstract down to 326 . A final full text screening reduced the number to 182 as listed in Table 3.

\subsection{Expert Interview}

Experts were interviewed to understand the perception and practices of risk management in new product development projects in the food industry. We also sought to understand new product development processes from the expert's experiences in her/his organisation. This included the involvement of their staff within each function and the process steps involved in the project risks. We selected experts from members of new product development teams in middle to large size companies, to ensure that they had some understanding of risk concept and the importance of risk management in their work. Eight experts from NPD projects in five companies were selected. Company profiles and industry segments are shown in Table 4.

\section{Finding}

Our findings were grouped into seven topics : 1) Classification of research method, 2) Project type and industry segment, 3) Distribution of articles by regions, 4) Tools and techniques for risk management, 5) Risk factor by project type, 6) Risk management practice in the food industry and 7) New product development and risk management processes in the food industry. The first five topic results are from the literature review; topics 6) and 7) give results from the expert interviews.

\subsection{Classification of Research Method}

The research methods have been classified into four groups according to Hendry and Nonthaleerak (2005), these are : descriptive, empirical, conceptual and the literature review. The description of each group is 
explained in Table 5 and the distributions are illustrated in Fig. 2.

\subsection{Project Type and Industrial Segment}

Our main focus for this study is risk management in New Product Development (NPD) processes. However, there are many research studies in other types of projects that use the same concept and methodology which can be applied in risk management for NPD. Our study also included the other main project types, such as construction, information technology, engineering and industrial projects. The distributions of selected articles by project type are shown in Fig. 3.

From a database of 182 selected articles, 29 indicated that the context of their study was in a specific industry segment. The rest were non-specific or related to more than one industry. The distribution of papers by segment can be seen in Fig. 4.

\subsection{Distribution of Articles by Regions}

This study also identified a location of research or location of author(s). Fig. 5 shows the distribution of the articles by region.

$36 \%$ of the studies on project risk management were conducted in Europe, followed by Asia and North America with $28 \%$ and $23 \%$ respectively. The major contributing country in Europe was the UK with Korea as the major contributor in Asia. The rest of the world contributed only $13 \%$ in total for research in this topic.

Table 3. Number of papers by database and screening process

\begin{tabular}{|c|c|c|c|c|}
\hline & ProQuest & EBSCOhost & Science Direct & Emerald \\
\hline Total Search results & 427 & 1507 & 248 & 89 \\
\hline $\begin{array}{l}\text { Exclude duplication from search } \\
\text { term }\end{array}$ & 293 & 701 & 204 & 80 \\
\hline Screen by title & 190 & 125 & 151 & 75 \\
\hline Screen by abstract & \multicolumn{4}{|c|}{326} \\
\hline Full text screening & \multicolumn{4}{|c|}{182} \\
\hline
\end{tabular}

Table 4. Company profile for expert interview

\begin{tabular}{|c|c|c|c|c|}
\hline Company & Project & Size & Segment in Food Industry & Product in case study \\
\hline A & 1,2 & Large* & Dairy and Milk Product & $\begin{array}{l}\text { Milk-powder products for Infants } \\
\text { and Children }\end{array}$ \\
\hline B & 3 & Large* & Non-Alcoholic Beverage & Beverage \\
\hline $\mathrm{C}$ & 4 & Large* & $\begin{array}{l}\text { Fishery products, Canned fish } \\
\text { and Others }\end{array}$ & Instant food in can \\
\hline $\mathrm{D}$ & $5,6,7$ & Large* & $\begin{array}{l}\text { Pet and Animal food, } \\
\text { Livestock product and Fishery } \\
\text { products }\end{array}$ & $\begin{array}{l}\text { Livestock feed, Frozen food and } \\
\text { Ready Meal Products }\end{array}$ \\
\hline $\mathrm{E}$ & 8 & Large* & Sugar and Sugar products & Sugar product \\
\hline
\end{tabular}

* Employee over 200 and turn over more than 200 Million Baht

Table 5. Research method and description

\begin{tabular}{|c|c|c|}
\hline Research Method & Description & No. of paper \\
\hline Descriptive & $\begin{array}{l}\text { Describe various expect, theory and tools for risk assessment } \\
\text { and risk management }\end{array}$ & 48 \\
\hline Empirical & $\begin{array}{l}\text { Survey, interview, case study, experimental, exploratory } \\
\text { based on empirical use and industrial case }\end{array}$ & 68 \\
\hline Conceptual & $\begin{array}{l}\text { Propose conceptual frame work, model and technique for risk } \\
\text { management }\end{array}$ & 51 \\
\hline Literature Review & Reviewing of research paper and past study & 15 \\
\hline
\end{tabular}




\subsection{Tools and Techniques for Risk Management}

From the literature review, tools have been used in two major areas of the risk management process for risk identification and risk analysis steps. The level of complexity of the tools starts with basic tools, such as risk breakdown structure by common risk category, risk matrix, trending to more complex ideas using probability and mathematic models for risk analysis.

The most frequently used tools in project risk management research are Failure Mode and Effect Analysis (FMEA), Analytic Hierarchy Process (AHP), Bayesian network (BN), Fuzzy set and Monte Carlo Simulation. A few papers used less popular tools, such as Bubble Diagrams (Abrahamsen \& Aven, 2011) and Control Charts (Hamza, 2009).

Another approach of the risk management study considered the project risk as the network and used network design to facilitate the evaluation of projects by determining the project execution risk. Examples of research using this approach can be found in a paper from Chin et al. (2009). A summary of tools and methodologies used for risk research management is shown in Table 6.

\subsection{Risk Factor by Project Type}

From the selected 182 papers, 18 focused on, or mentioned risk factor. These risk factors can be summarized by project type in four groups consisting of: 1) NPD , 2) IT, 3) Construction and 4) Non-Specific types of project.

Each type seems to focus on different areas of risk. NPD projects are more focused on the internal processes within the organisation, while construction projects also consider factors from stakeholders outside the project. IT projects seem to have a good balance of risk assessment both for internal and external factors. (See details in Appendix).

\subsection{Risk Management Practice in Food Industry}

During their interviews the experts were asked about the risk management practices in NPD used in their own organisations. The responses can be divided into 3 groups :

1) No risk management process. This group did not usually conduct risk assessment during project innovation due to lack of process knowledge by the NPD team. They may not have realised the importance of risk management in their projects. An example of this group was found in interview no. 3

2) Non-systematic risk management. This group may have conducted risk assessment during some steps in high risk projects, but did not use systematic methods or tools for risk management. This practice was found in case nos. $4,5,6,7$ and 8 .

3) Systematic risk management. This group followed the correct processes and included risk management as part of their standard work procedure. This case was found in interviews no. 1 and 2

\subsection{New Product Development and Risk Management Process in Food Industry}

A summary of the importance of risk factors from each interview and the requirement for risk management tools is shown summarized in Table 7.

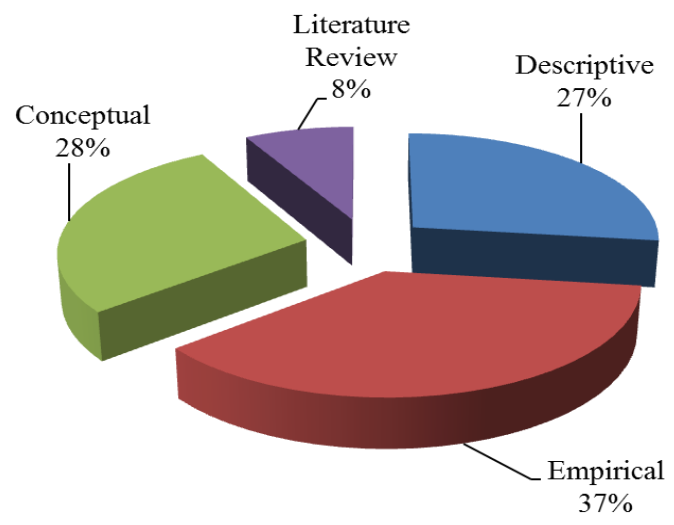

Fig. 2. Distribution of papers by research method

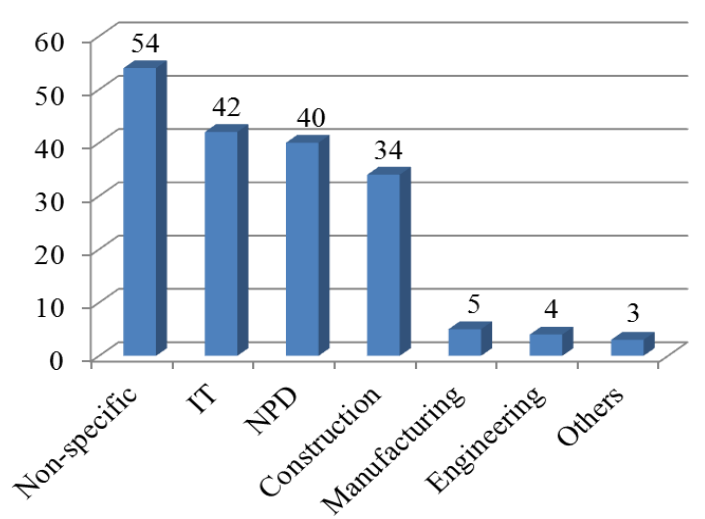

Fig. 3. Distribution of articles by project types

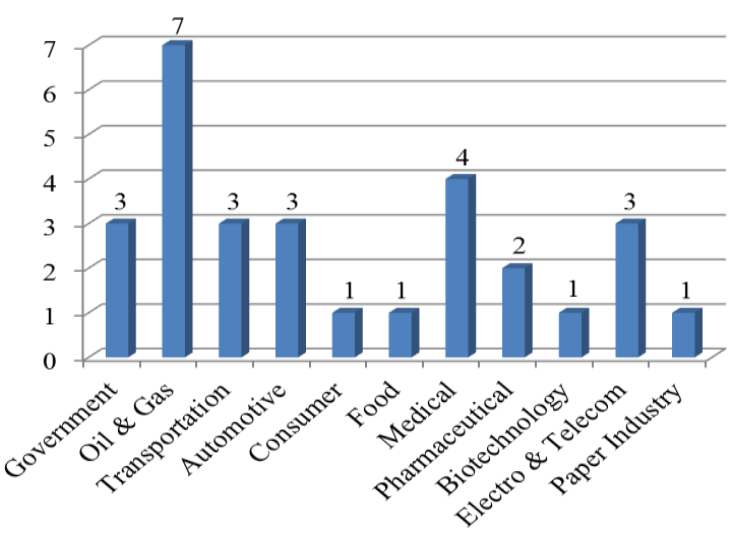

Fig. 4. Distribution of articles by industrial segment

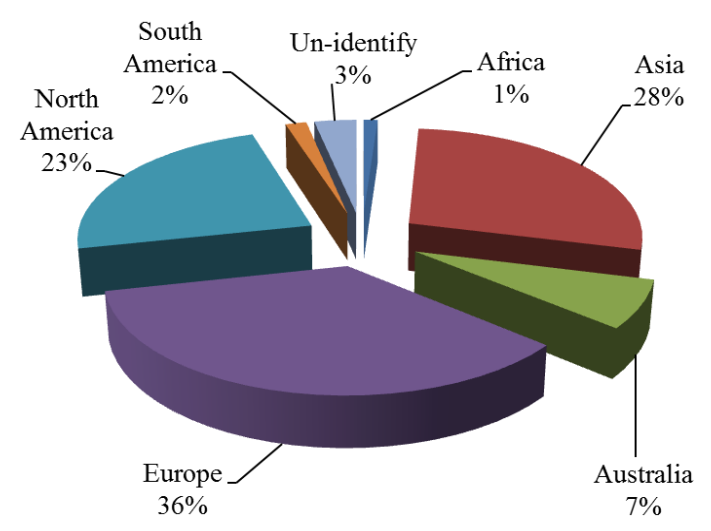

Fig. 5. Distribution of articles by region 
Table 6. Tools and methodology used in project risk management research

\begin{tabular}{ll}
\hline \multicolumn{1}{c}{$\begin{array}{c}\text { Tools \& Methodologies for Risk } \\
\text { management }\end{array}$} & \multicolumn{1}{c}{ Reference Articles } \\
\hline Analytic Hierarchy Process (AHP) & $\begin{array}{l}\text { Badri et al., 2012; Dey, 2002; Jaskowski and Biruk, 2011; Kayis et al., } \\
\text { 2006; Kayis et al. ,2007; Dey, 2010; Nieto-Morote and Ruz-Vila, 2011 }\end{array}$ \\
Bayesian network (BN) & Al-Rousan et al., 2009; Lee et al., 2009; Chin et al., 2009; Fan and Yu, \\
& 2004 and Hu et al., 2012 \\
FMEA & Carbone and Tippett, 2004; Segismundo and Miguel, 2008; Zeng et al., \\
& 2010; Zhang and Chu, 2011 \\
& Abdelgawad and Fayek, 2010; Choi and Ahn ,2010; Tüysüz and Kahraman, \\
Fuzzy set & 2006; Zeng and Smith, 2007; Ismail et al., 2008; Zou and Li, 2010; Wei \\
& and Chang, 2011 \\
Expected utility theory & Kutsch and Hall, 2005; Miles, 2004 \\
Game theory & Zhao and Jiang, 2009 \\
Monte Carlo Simulation & Liou et al., 2012; Sharma and Suri, 2011; Turgut and Baykoc, 2007 and \\
Bubble Diagrams & Vanhoucke, 2012 \\
Control Charts & Abrahamsen and Aven, 2011 \\
\hline
\end{tabular}

Table 7. NPD process and risk management activity

\begin{tabular}{|c|c|c|c|}
\hline Expert & Products & Important risk & Requirement for risk management tools \\
\hline 1 & $\begin{array}{l}\text { Milk-powder products } \\
\text { for Infants under } 1 \text { year }\end{array}$ & Regulatory and material sourcing & Support risk identification in early stage \\
\hline 2 & $\begin{array}{l}\text { Milk-powder products } \\
\text { for Children over } 3 \text { year }\end{array}$ & $\begin{array}{l}\text { Regulatory and customer acceptance } \\
\text { (taste) }\end{array}$ & Suggestion for risk response \\
\hline 3 & Soft drink & $\begin{array}{l}\text { Substitute product from competitor } \\
\text { Distribution channel }\end{array}$ & Navigate risk management process \\
\hline \multirow[t]{3}{*}{4} & Instant food in can & $\begin{array}{l}\text { Distribution channel and timeline for } \\
\text { product launch }\end{array}$ & Risk identification and Evaluation \\
\hline & & $\begin{array}{l}\text { FDA registration } \\
\text { No information support for key } \\
\text { decision }\end{array}$ & \\
\hline & & Confidentiality in new product launch & \\
\hline 5 & Livestock feed & $\begin{array}{l}\text { Safety Risk } \\
\text { Management support } \\
\text { Communication }\end{array}$ & Risk identification \\
\hline 6 & Frozen food & $\begin{array}{l}\text { Raw materials quality } \\
\text { Alignment with business strategy }\end{array}$ & $\begin{array}{l}\text { Guidance for formal risk management } \\
\text { process }\end{array}$ \\
\hline \multirow[t]{3}{*}{7} & Ready meal product & $\begin{array}{l}\text { Change in company direction } \\
\text { Customer requirement change or life } \\
\text { style change }\end{array}$ & $\begin{array}{l}\text { Compatible with NPD process used by } \\
\text { organization }\end{array}$ \\
\hline & & $\begin{array}{l}\text { Change in local/export country } \\
\text { regulation }\end{array}$ & \\
\hline & & Materials shortage from outbreak & \\
\hline 8 & Sugar product & Customer and Market acceptant & $\begin{array}{l}\text { High precision, include all process step, } \\
\text { and can be customized }\end{array}$ \\
\hline
\end{tabular}




\section{Proposed Risk Management Model}

A risk management model for NPD in the food industry is proposed in Fig. 6. It consists of a risk management process in five steps: 1) Scope and context planning, 2) Risk identification, 3) Risk analysis, 4) Risk treatment and control and 5) Risk-Benefit Analysis. These risk identification steps will be conducted in each of the NPD processes.

Common risk factors from the literature review and additional risks from the expert interviews can be summarized as 10 common risk factors for the Risk Management Model for NPD.

The descriptions of all the common risk factors are shown in Table 8. NPD teams can use this list in the Risk Identification phase to explore project risks in all dimensions.

Risk analyses will be quantified by a rating score on the impact to project objective and sustainable growth of the organisation, multiplied by the probability of occurrence score, detection and response. High priority risks will be managed by risk response and control processes in seven alternative ways (ISO31000, 2009) : a) avoiding the risk by deciding not to start or continue with the activity that gives rise to the risk, b) taking or increasing the risk in order to pursue an opportunity, c) removing the risk source, d) changing the likelihood, e) changing the consequences, f) sharing the risk with another party or parties (including contracts and risk financing), and g) retaining the risk by informed decision.

The final process step for NPD project risk management is risk-benefit analysis to consider the overall risk of each project compared to the benefit. This process is recommended in BSI 7000-1 by BSI (2008) to manage portfolios of innovation projects in organisations.

\section{Discussion and Conclusion}

The study of the international standard and PMBOK related to project risk shows well established theory and alignment of project and risk management. These standards provide process steps, including suggestions for tools and techniques that can be applied in various project types. However, these standards and guidelines did not address the different characteristics of project type. They also did not consider the specific requirements for each type of application. This is an opportunity for future research on project and risk management in a specific area or industrial context.

A literature review of research papers showed that the majority of researchers also understand this requirement and attempt to address these contextual issues. Many research papers focus on the empirical study of project risk management using survey, interview, case study or experimental techniques. They explore the problems, issues and effectiveness on the empirical use of risk management methods and tools for business cases in specific areas or specific project applications. More data and knowledge to support the risk management process in project execution is required rather than the development of new theories for risk management.

From the literature review we see that there is a greater risk inherent in NPD, compared to other project types. Nevertheless, the research papers did not focus on the problem of low acceptance and utilisation of systematic risk management for NPD. This is an opportunity for future research work.

This study also looked at tools and techniques used in project risk management. There are various standard tools and techniques used for different purposes in each step of the risk management process. Some classic tools such as FMEA are still used in many research areas, such as the recent study on the financial impact of risk factors by Buertey et.al. (2013). The paper by Pons (2008) examined the correlation of the project management body of knowledge with new product development and concluded that the former method, with its structured task definition and software tools, is generally useful for managing NPD projects. However, in some areas, project management does not meet the needs of NPD and there is opportunity for improvement. Another study by Zwikael and Ahn (2011) identified the problems of existing tools that are 'too complicated' for users. As the size and complexity of a project increases, the effort required for effective risk planning rises exponentially, making the tools difficult to use. Another study about risk management tools development for NPD projects by Kayis et al. (2007) discussed the gap in commercial-off-the-shelf software. This lacked the capability to support project risk identification, analysis and mitigation of risk during the life cycle of the project, because this software is mainly designed for risk analysis and assessment. Both the identification and analysis phases of the risk management process are considered equally important (Maytorena et al., 2007). However, most studies focus on risk analysis, leaving the risk identification phase to be handled by the NPD team or project manager who may underestimate the risk (Kutsch, 2008; Kutsch and Hall, 2010).

The risk management model proposed here aims to address most of the research gaps and specific requirements of NPD activities in the food industry. The model is developed from universal and internationally accepted risk management processes, project management standards, academic research and expert analysis from the food industry to ensure compliance with industrial standards. It addresses the specific needs of NPD in the context of the food industry. This model will be validated by further study and used for the development of risk management tools for use in systematic risk management processes for future NPD projects in the food industry. 


\section{NPD Process Step}

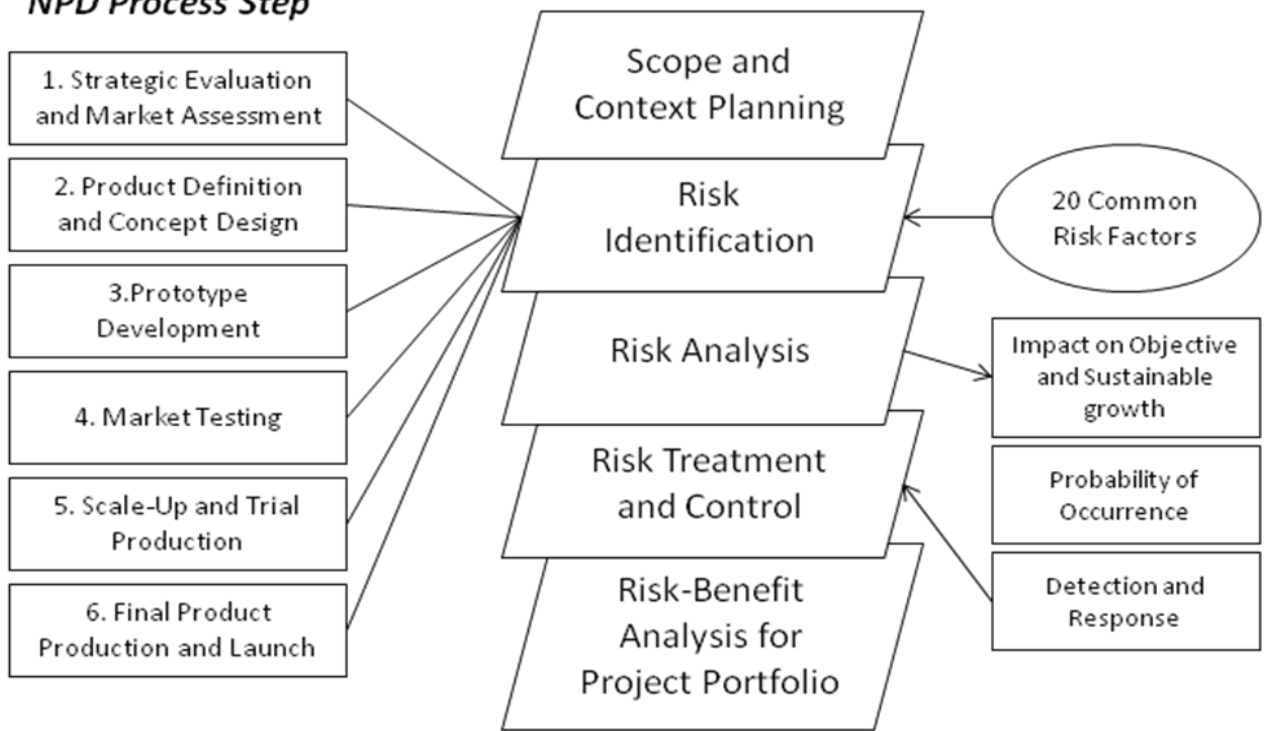

Fig. 6. Proposed Risk Management Model

Table 8. Common Risk Factor for NPD

\begin{tabular}{|c|c|c|}
\hline No. & Risk Factors & Description \\
\hline 1 & Schedule risk & Risk relate to project scheduling and time estimation \\
\hline 2 & Organization structure & Structure of NPD team and support \\
\hline 3 & Project communication & Report and information sharing \\
\hline 4 & Economic risk & Economic and financial status \\
\hline 5 & Technical complexity & Level of technical complexity \\
\hline 6 & Location selection & Plant location and materials source \\
\hline 7 & Resource planning & Resources and facilities to support NPD activities \\
\hline 8 & Team knowledge & NPD team experience and knowledge \\
\hline 9 & Design risk & Design concept and uses of VOC \\
\hline 10 & Manufacturing technology & Risk from manufacturing technology selection \\
\hline 11 & Intellectual properties & Limitation from patents and license \\
\hline 12 & Sourcing and materials planning & Risk from materials availability and continuous supply \\
\hline 13 & Customer requirement & Requirement understanding and testing procedure \\
\hline 14 & Manufacturing capability & Availability and sustainability of manufacturing capacity \\
\hline 15 & Logistic \& Transportation & Selection of logistic network and transportation mode \\
\hline 16 & Procurement and contract & Risk from outsourcing activities and contract \\
\hline 17 & Social risk & Risk relate to community, social responsibility and environment \\
\hline 18 & Political risk & Political situation affect to project \\
\hline 19 & Natural risk & Natural disasters and climate change \\
\hline 20 & Compliance risk & Risk relates to law and regulations \\
\hline
\end{tabular}




\section{References}

Abdelgawad, M. and Fayek, A. R. (2010). Risk management in the construction industry using combined fuzzy FMEA and fuzzy AHP. Journal of Construction Engineering and Management, 136(9), 1028-1036.

Abrahamsen, E. B. and Aven, T. (2011). Safety oriented bubble diagrams in project risk management. International Journal of Performability Engineering, 7(1), 91.

Ahlemann, F., El Arbi, F., Kaiser, M. G., and Heck, A. (2012). A process framework for theoretically grounded prescriptive research in the project management field. International Journal of Project Management, 31(1), 43-56.

Aleixo, G. G. and Tenera, A. B. (2009). New product development process on High-Tech innovation life cycle. World Academy of Science, Engineering and Technology, 58.

Al-Rousan, T., Sulaiman, S., and Salam, R. A. (2009). WPRiMA tool: managing risks in Web projects. Proceedings of World Academy of Science: Engineering \& Technology, 50, 627-633.

Aloini, D., Dulmin, R., and Mininno, V. (2012). Modelling and assessing ERP project risks: A Petri Net approach. European Journal of Operational Research, 220(2), 484-495.

Badri, A., Nadeau, S., and Gbodossou, A. (2012). Proposal of a risk-factor-based analytical approach for integrating occupational health and safety into project risk evaluation. Accident Analysis \& Prevention, 48, 223-234.

BSI (2008). BSI 7000-1. Design management systems. Guide to managing innovation. London, UK: The Brithish Standard Institution.

Carbone, T. A. and Tippett, D. D. (2004). Project risk management using the project risk FMEA. Engineering Management Journal, 16(4), 28-35.

Chapman, C. and Ward, S. (2004). Why risk efficiency is a key aspect of best practice projects. International Journal of Project Management, 22(8), 619-632.

Chin, K. S., Tang, D. W., Yang, J. B., Wong, S. Y., and Wang, H. (2009). Assessing new product development project risk by Bayesian network with a systematic probability generation methodology. Expert Systems with Applications, 36(6), 9879-9890.

Choi, H. G. and Ahn, J. (2010). Risk analysis models and risk degree determination in new product development: A case study. Journal of Engineering and Technology Management, 27(1), 110-124.

Cooper, L. P. (2003). A research agenda to reduce risk in new product development through knowledge management: a practitioner perspective. Journal of Engineering and Technology Management, 20(1), 117-140.

Cooper, R. G. (1990). Stage-gate systems: a new tool for managing new products. Business Horizons, 33(3), 44-54.

Cooper, R. G. and Kleinschmidt, E. J. (1991). New product processes at leading industrial firms. Industrial Marketing Management, 20(2), 137-147.

Cooper, R. G. (1994). Perspective third-generation new product processes. Journal of Product Innovation Management, 11(1), 3-14.
Dey, P. K. (2002). Project risk management: a combined analytic hierarchy process and decision tree approach. Cost Engineering, 44(3), 13-27.

Dey, P. K. (2010). Managing project risk using combined analytic hierarchy process and risk map. Applied Soft Computing, 10(4), 990-1000.

Fan, C. F. and Yu, Y. C. (2004). BBN-based software project risk management. Journal of Systems and Software, 73(2), 193-203.

Francis, M. (2006), "Stage model research in the UK fast moving consumer goods industry", International Journal of Logistics Research and Applications, 9(4), 351-68.

Glueck-Chaloupka, A. A., Capella, L. M., and Coggins, P. C. (2005). Food product development, food regulations and policies - compatible or not?. Journal of Nonprofit \& Public Sector Marketing, 13(1-2), 199212.

Hamza, S. E. A. (2009). Monitoring and controlling design process using control charts and process sigma. Business process management Journal, 15(3), 358370.

Hendry, L. and Nonthaleerak, P. (2005). Six sigma: Literature review and key future research areas, The Department of Management Science, Lancaster University Management School, Lancaster LA1 4YX, UK.

Hu, Y., Mo, X., Zhang, X., Zeng, Y., Du, J., and Xie, K. (2012). Intelligent analysis model for outsourced software project risk using constraint-based bayesian network. Journal of Software, 7(2), 440-449.

HÜSIG, S., KOHN, S., and POSKELA, J. (2005). The Role of Process Formalisation in the early Phases of the Innovation Process. In 12th Int. Prod. Development Conf. Copenhagen.

Ignatius Teye Buertey, J., Abeere-Inga, E., and Adjei Kumi, T. (2013). The financial impact of risk factors affecting project cost contingency: evidential reasoning method. Journal of Engineering, Project \& Production Management, 3(2).

Ismail, A., Abbas, M. A., and Zamri, B. C. (2008). Approach to analyze risk factors for construction projects utilizing fuzzy logic. Journal of Applied Sciences, 8, 3738-3742.

ISO (2003). ISO 10006:2003 Quality management systems - Guidelines for quality management in projects. Geneva, Switzerland.

ISO (2009). ISO31000:2009 Risk management Principles and Guidelines, International Organization for Standardization. Geneva, Switzerland.

ISO (2012). ISO 21500:2012 Guidance on project management. Geneva, Switzerland.

Jafari, M., Rezaeenour, J., Mazdeh, M. M., and Hooshmandi, A. (2011). Development and evaluation of a knowledge risk management model for projectbased organizations: A multi-stage study. Management Decision, 49(3), 309-329.

Jaskowski, P. and Biruk, S. (2011). The conceptual framework for construction project risk assessment. Reliability: Theory \& Applications, 3(1), 27-35.

Kayis, B., Arndt, G., Zhou, M., Savci, S., Khoo, Y. B., and Rispler, A. (2006). Risk quantification for new product design and development in a concurrent engineering environment. CIRP AnnalsManufacturing Technology, 55(1), 147-150. 
Kayis, B., Zhou, M., Savci, S., Khoo, Y. B., Ahmed, A., Kusumo, R., and Rispler, A. (2007). IRMASdevelopment of a risk management tool for collaborative multi-site, multi-partner new product development projects. Journal of Manufacturing Technology Management, 18(4), 387-414.

Keizer, J. A., Vos, J. P., and Halman, J. I. (2005). Risks in new product development: devising a reference tool. $R \& D$ Management, 35(3), 297-309.

Keizer, J. A. and Halman, J. I. (2007). Diagnosing risk in radical innovation projects. Research-Technology Management, 50(5), 30-36.

Koen, P., Ajamian, G., Burkart, R., Clamen, A., Davidson, J., D'Amore, R., Elkins, C.,Herald, K., Incorvia, M., Johnson, A.,Karol, R.,Seibert, R.,Slavejkov, A., and Wagner, K. (2001). Providing clarity and a common language to the 'fuzzy front end.'. Research Technology Management, 44(2), 46.

Kutsch, E. and Hall, M. (2005). Intervening conditions on the management of project risk: dealing with uncertainty in information technology projects. International Journal of Project Management, 23(8), 591-599.

Kutsch, E. (2008). The effect of intervening conditions on the management of project risk. International Journal of Managing Projects in Business, 1(4), 602-610.

Kutsch, E. and Hall, M. (2010). Deliberate ignorance in project risk management. International journal of project management, 28(3), 245-255.

Lee, E., Park, Y., and Shin, J. G. (2009). Large engineering project risk management using a Bayesian belief network. Expert Systems with Applications, 36(3), 5880-5887.

Liou, F. M., Huang, C. P., and Chen, B. (2012). Modeling government subsidies and project risk for financially non-viable build-operate-transfer (BOT) projects. Engineering Management Journal, 24(1), 58-64.

Maytorena, E., Winch, G. M., Freeman, J., and Kiely, T. (2007). The influence of experience and information search styles on project risk identification performance. Engineering Management, IEEE Transactions on, 54(2), 315-326.

Miles, R. F. (2004). Risk - adjusted mission value: trading off mission risk for mission value. Risk analysis, 24(2), 415-424.

Milosevic, D. and Patanakul, P. (2005). Standardized project management may increase development projects success. International Journal of Project Management, 23(3), 181-192.

Nieto-Morote, A. and Ruz-Vila, F. (2011). A fuzzy approach to construction project risk assessment. International Journal of Project Management, 29(2), 220-231.

Pinto, J. K. and Covin, J. G. (1989). Critical factors in project implementation: a comparison of construction and R\&D projects. Technovation, 9(1), 49-62.

PMI (2008). A guide to the project management body of knowledge: PMBOK guide, 4th ed. PMI - Project Management Institute, Pennsylvania, USA.

PMI (2009). Practice standard for project risk management. PMI - Project Management Institute, Pennsylvania, USA.

PMI (2013) A Guide to the Project Management Body of Knowledge: PMBOK Guide, 5th ed., PMI - Project Management Institute, Pennsylvania, USA.
Pons, D. (2008). Project management for new product development. Project Management Journal, 39(2), 82-97.

Schroeder, R. G. (2003) Operations management: Contemporary concepts and cases. International Edition, McGraw-Hill.

Segismundo, A. and Miguel, P. A. C. (2008). Failure mode and effects analysis (FMEA) in the context of risk management in new product development: A case study in an automotive company. International Journal of Quality \& Reliability Management, 25(9), 899-912.

Sharma, I. and Suri, P. K. (2011). Schedule risk analysis simulator using beta distribution. International Journal on Computer Science and Engineering, 3(6), 2408-2414.

Standards Australia (2004). Risk Management AS/NZS 4360:2004, Standards Association of Australia, Strathfield.

Stevens, G. A. and Burley, J. (2003). Piloting the rocket of radical innovation. Research Technology Management, 46(2), 16-25.

Suwannaporn, P. and Speece, M. W. (2010). Assessing new product development success factors in the Thai food industry. British Food Journal, 112(4), 364-386.

Thal Jr, A. E., Badiru, A., and Sawhney, R. (2007). Distributed project management for new product development. IJEBM, 5(2), 93-104.

Turgut, A. E. and Baykoc, Ö. F. (2007). Monte carlo simulation and risk analysis application for the project of constitution of numbering regime in the telecommunication networks. Computers \& Applied Sciences Complete. Teknoloji, 10(3), 203-214.

Tüysüz, F. and Kahraman, C. (2006). Project risk evaluation using a fuzzy analytic hierarchy process: An application to information technology projects. International Journal of Intelligent Systems, 21(6), 559-584.

Ulrich, K. T. and Eppinger, S. D. (2008) Product design and development- Forth Edition. New York, McGraw-Hill.

Vanhoucke, M. (2012). Measuring the efficiency of project control using fictitious and empirical project data. International Journal of Project Management, 30(2), 252-263.

Varkey, P., Horne, A., and Bennet, K. E. (2008). Innovation in health care: a primer. American Journal of Medical Quality, 23(5), 382-388.

Wei, C. C. and Chang, H. W. (2011). A new approach for selecting portfolio of new product development projects. Expert Systems with Applications, 38(1), 429-434.

Winger, R. and Wall, G. (2006). Food product innovation: a background paper. Agricultural and Food Engineering Working Document 2, FAO, Rome.

Zeng, J., An, M., and Smith, N. J. (2007). Application of a fuzzy based decision making methodology to construction project risk assessment. International journal of project management, 25(6), 589-600.

Zeng, S. X., Tam, C. M., and Tam, V. W. (2010). Integrating safety, environmental and quality risks for project management using a FMEA method. Inzinerine Ekonomika-Engineering Economics, 21(1), 44-52.

Zhang, Z. and Chu, X. (2011). Risk prioritization in failure mode and effects analysis under uncertainty. Expert Systems with Applications, 38(1), 206-214. 
Zhao, L. and Jiang, Y. (2009). A game theoretic optimization model between project risk set and measure set. International journal of information technology \& decision making, 8(04), 769-786.

Zou, P. X. and Li, J. (2010). Risk identification and assessment in subway projects: case study of Nanjing Subway Line 2. Construction Management and Economics, 28(12), 1219-1238.

Zwikael, O. and Ahn, M. (2011). The effectiveness of risk management: an analysis of project risk planning across industries and countries. Risk Analysis, 31(1), 25-37.

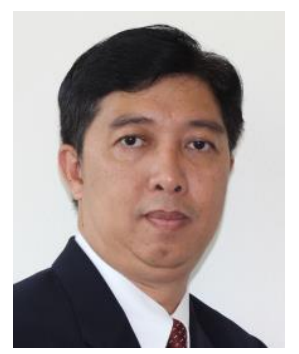

Dundusid Porananond is a $\mathrm{PhD}$ candidate in Technopreneurship and Innovation management Program at Chulalongkorn University, Thailand. He holds a Master degree in Internet and E-Commerce Technology, Assumption University and a Bachelor degree in Chemical Engi-neering, Chulalongkorn University. His main research interest is in the field of innovation management, project management and operation management. He has more than 20 years working experiences in manufacturing and supply chain management for food, chemical, electronic and health care industry, and also has several professional certifications in project management and supply chain management.

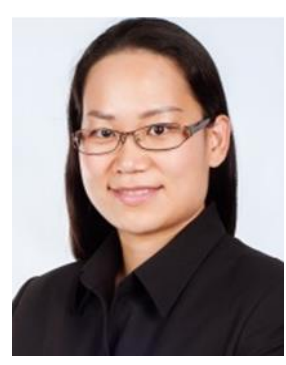

Natcha Thawesaengskulthai is a Vice Dean at Faculty of Engineering and Assistant Professor at Industrial Engineering, Chulalongkorn University, Thailand. She has expertise in quality management, operations management, and innovation management and substantial industrial experience in manufacturing and service operations.

Dr.Natcha is the author of more than forty publications in the fields of quality management, innovation management, quality engineering techniques, and improvement initiatives. 


\section{Appendix}

Summary of risk factors in risk management research.

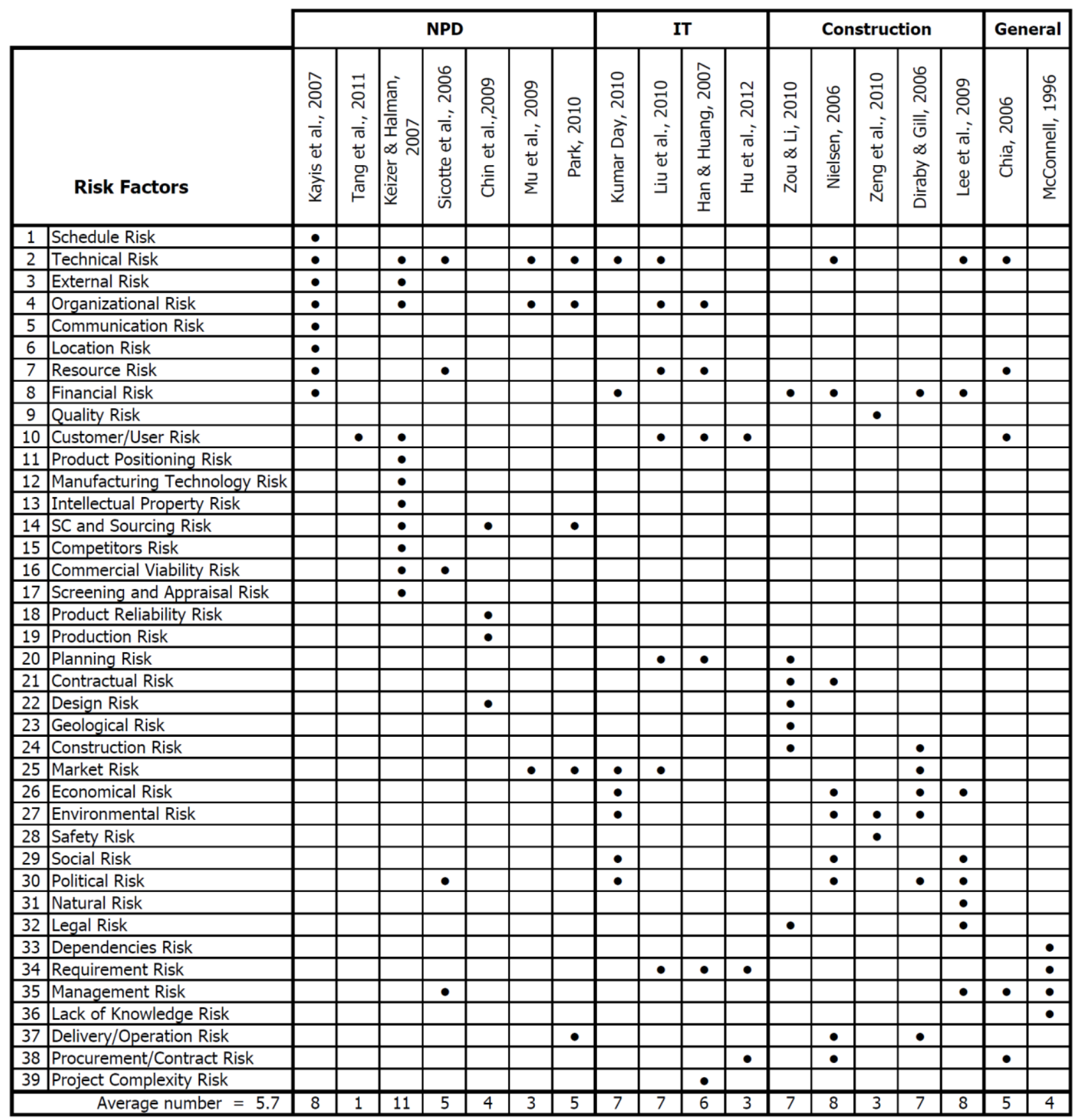

